\section{The Effect of Increasing Application Rates of Nine Plant Growth Regulators on the Turf and Stolon Characteristics of Pot-grown 'Patriot' Hybrid Bermudagrass}

\author{
Marco Volterrani ${ }^{1}$, Nicola Grossi ${ }^{1}$, Monica Gaetani ${ }^{1}$, \\ Lisa Caturegli ${ }^{1}$, Aimila-Eleni Nikolopoulou ${ }^{2}$, Filippo Lulli $^{3}$, and \\ Simone Magni ${ }^{1,4}$
}

ADDITIONAL INDEX wORDs. warm-season turfgrass propagation, GA inhibitors, herbicides, hormonal compounds

SUMMARY. Vegetatively propagated warm-season turfgrasses are established with methods that rely on large quantities of propagation material and subsequent plant growth support. The precision seeding adopted for some seed propagated crops controls the depth and spacing at which seeds are placed in the soil. Sprigs that are reduced in length could potentially be suitable for existing machinery, and precision planting could enhance the efficiency of use of the propagation material. The aim of the present study was to carry out a preliminary screening on products known to act as plant growth regulators to explore their potential use for controlling stolon development and elongation of 'Patriot' hybrid bermudagrass (Cynodon dactylon $\times$ C. transvaalensis) grown in pots for propagation purposes. Trinexapac-ethyl (TE), chlormequat chloride (CM), paclobutrazol (PB), propiconazole (PPC), diquat (DQ), flazasulfuron (FS), glyphosate (GP), ethephon (EP), and gibberellic acid (GA) were applied to pot-grown 'Patriot' hybrid bermudagrass turf in eight different application rates, ranging for each product from the minimum expected effective rate to a potentially harmful rate. Of the tested treatments, TE applied at $2.0 \mathrm{~kg} \cdot \mathrm{ha}^{-1}$ and $\mathrm{PB}$ applied at $1.0 \mathrm{~kg} \cdot \mathrm{ha}^{-1}$ reduced stolon and internode length without causing a reduction in the stolon number or turf quality. PPC was also effective in reducing stolon length, but the effect on internode length was not statistically significant. Stolon length was unaffected by CM, while DQ and GP induced stolon elongation. FS, EP, and GA affected stolon length without a consistent relation between stolon length and application rate. The chemical suppression of stolon elongation in pot-grown 'Patriot' hybrid bermudagrass can contribute to controlling sprig size for use with precision seeding machinery.

$\mathrm{T}$ he vegetative establishment of warm-season turfgrasses is achieved by spreading large quantities of propagation material at the soil surface and subsequently encouraging growing points to generate new plants (Dunn and Diesburg, 2004). A more efficient use of the propagation material by placing sprigs at a pre-established precise depth in the soil and with defined spacing is expected to produce a higher percentage of buds converted into new stems and a more uniform plant density. Precision seeding is routinely adopted for several field crops. Properly sized

${ }^{1}$ Department of Agriculture, Food, and Environment, University of Pisa, Italy

${ }^{2}$ Department of Crop Science, Agricultural University of Athens, Greece

${ }^{3}$ Turf Europe R\&D, Pisa, Italy

${ }^{4}$ Corresponding author. E-mail: simone.magni@ unipi.it. sprigs could fit precision seeding machinery thus with the potential of being planted at a defined depth and spacing.

Plant growth regulators (PGRs) are known for their ability to modify plant organ development and elongation due to their interference with plant metabolism (Ervin and Zhang, 2008; Huang, 2007).
Gibberellic acid inhibitors such as TE and PB routinely are used in fine turfs. Treatments are carried out to reduce leaf growth or seed head formation while preserving stolon growth (McCarty, 2011). Volterrani et al. (2012) reported a significant reduction of stolon length when TE was applied on 'Patriot' hybrid bermudagrass over the labeled rate. The available data on hybrid bermudagrass for $\mathrm{PB}$ only refers to the effects on clipping yield, root mass, root length, and shoot density of dwarf types (McCullough, 2005a, 2005b).

Chlormequat chloride also belongs to the group of GA inhibitors but is currently labeled for grain crops and ornamental plants. Its use on hybrid bermudagrass was reported by Youngner and Nudjie (1974) who recorded a slight delay in root growth, a decrease in internode elongation, and a nodal branching stimulation.

The potential use of triazoles as plant growth regulators, such as $\mathrm{PB}$ and PPC, was first attributed to their interference with the GA synthesis pathway (Fletcher et al., 2000). Brassinosteroids were then identified as phytohormones involved in several growth responses such as cell and stem elongation, and PPC has been recognized as a specific suppressor of their synthetic pathway (Hartwig et al., 2012; Sekimata et al., 2002). The application of PPC as a plant growth regulator on turfgrasses was reported by Ervin et al. (2004) who recorded an increase in quality and color when $0.22 \mathrm{~kg} \cdot \mathrm{ha}^{-1}$ PPC were applied to a creeping bentgrass (Agrostis stolonifera) sward grown in shaded conditions.

In addition to products intended for growth regulation, several other compounds are known to induce growth suppression. A number of

\begin{tabular}{llll}
\hline $\begin{array}{l}\text { Units } \\
\text { To convert U.S. to SI, } \\
\text { multiply by }\end{array}$ & U.S. unit & SI unit & $\begin{array}{l}\text { To convert SI to U.S., } \\
\text { multiply by }\end{array}$ \\
\hline 0.3048 & $\mathrm{ft}$ & $\mathrm{m}$ & 3.2808 \\
9.3540 & gal $/ \mathrm{acre}$ & $\mathrm{L} \cdot \mathrm{ha}^{-1}$ & 0.1069 \\
2.54 & inch $(\mathrm{es})$ & $\mathrm{cm}$ & 0.3937 \\
25.4 & inch(es) & $\mathrm{mm}$ & 0.0394 \\
6.4516 & inch & $\mathrm{cm}^{2}$ & 0.1550 \\
1.1209 & lb/acre & $\mathrm{kg} \cdot \mathrm{ha}^{-1}$ & 0.8922 \\
4.8824 & $\mathrm{lb} / \mathrm{ft}^{2}$ & $\mathrm{~kg} \cdot \mathrm{m}^{-2}$ & 0.2048 \\
1 & $\mathrm{mmho} / \mathrm{cm}$ & $\mathrm{dS} \cdot \mathrm{m}^{-1}$ & 1 \\
28.3495 & $\mathrm{oz}$ & $\mathrm{g}$ & 0.0353 \\
$\left({ }^{\circ} \mathrm{F}-32\right) \div 1.8$ & $\mathrm{o} F$ & ${ }^{\circ} \mathrm{C}$ & $\left({ }^{\circ} \mathrm{C} \times 1.8\right)+32$ \\
& & &
\end{tabular}


Table 1. Plant growth regulators (PGRs) applied at increasing rates on pot-grown 'Patriot' hybrid bermudagrass to control stolon development and elongation: classification, common name, commercial products used with the relative active ingredient concentration, and abbreviation adopted.

\begin{tabular}{|c|c|c|}
\hline PGR classification and common name ${ }^{z}$ & Commercial product (\% a.i.) & Abbreviation \\
\hline \multicolumn{3}{|l|}{ Class A: Late gibberellic acid inhibitors } \\
\hline Trinexapac-ethyl & Primo Maxx; Syngenta, Basel, Switzerland (11.3) & TE \\
\hline Chlormequat chloride & Cycocel 5 C; BASF, Ludwigshafen, Germany (46.1) & $\mathrm{CM}$ \\
\hline Paclobutrazol & Cultar, Syngenta $(25)$ & $\mathrm{PB}$ \\
\hline Propiconazole & Lizocin; Everris Italia, Treviso, Italy (25) & PPC \\
\hline Flazasulfuron & Chikara 25 WG; ISK Bioscience Europe, Brussels, Belgium (25) & FS \\
\hline Glyphosate & Clinic 360 SL; Nufarm, Linz, Austria (36) & GP \\
\hline \multicolumn{3}{|l|}{ Class E: Hormonal compounds } \\
\hline Ethephon & Ethrel; Bayer, Leverkusen, Germany (39.6) & $\mathrm{EP}$ \\
\hline Gibberellic acid $\left(\mathrm{GA}_{3}\right)$ & Berelez 40 SG, Syngenta (40) & GA \\
\hline
\end{tabular}

${ }^{2}$ PGRs are listed according to the classification proposed in Ervin and Zhang (2008).

active ingredients that are listed in herbicides share a similar mode of action with PGRs and, when applied to plants at rates far below the recommended rate for herbicidal action, they produce sublethal effects that result in growth suppression (Ervin and Zhang, 2008).

DQ is listed as a growth inhibitor herbicide, but little is known about its use on turfgrasses. Suppression of flower initiation in sugarcane (Saccharum officinarum) (Meyer et al., 2013) seems to be the only current use of DQ as a growth regulator. FS belongs to the sulfonylurea herbicides, some of which are listed as growth regulators (Watschke et al., 1992). McCullough et al. (2011) tested FS for the plant growth regulation of seashore paspalum (Paspalum vaginatum), achieving up to $75 \%$ clipping reduction and up to $86 \%$ seed head suppression compared with the untreated control.

Glyphosate inhibits the aromatic amino acid biosynthesis, which ultimately leads to a slow cessation of growth (Arteca, 1996). Johnson (1990) documented plant growth reduction on bahiagrass (Paspalum notatum) treated with the isopropylamine GP salt at $0.2 \mathrm{~kg} \cdot \mathrm{ha}^{-1}$.

$\mathrm{EP}$ and GA are classified as hormonal compounds because they are phytohormones or mimic the action of phytohormones (Ervin and Zhang, 2008). GA is labeled for turfgrass use with the aim of initiating or maintaining growth and preventing color changes in bermudagrasses (Cynodon sp.) during periods of cold stress
(Ervin and Zhang, 2008). Besides these effects, the increase in stolon growth has been reported for common bermudagrass (Cynodon dactylon) (Juska, 1958).

EP is labeled for annual bluegrass (Poa annua) seed head suppression and for regulating the growth of cool season turfgrasses; however, experimental applications on bermudagrasses have been reported by several authors (Brosnan et al., 2010; McCarty et al., 2011; McCullough et al., 2004). Results obtained by Shatters et al. (1998) indicated an increase in the rate of shoot formation from crowns of 'Tifton 85 ' common bermudagrass treated with EP.

Most information on PGRs is related to field applications for biomass reduction, and little is known about stolon growth regulation in pot-grown turfgrasses. We carried out a preliminary screening on products known to act as PGRs to explore their potential use for controlling stolon development and elongation in pot-grown hybrid bermudagrass. We also assessed the effects of tested treatments on sward characteristics to identify the products or application rates that are potentially harmful to plants.

\section{Materials and methods}

The trial was carried out at the Department of Agriculture, Food and Environment of the University of Pisa (lat. $43^{\circ} 40^{\prime} \mathrm{N}$, long. 10 $0^{\circ} 19^{\prime} \mathrm{E}, 6 \mathrm{~m}$ elevation) from April to July 2013. On 17 Apr. 2013 sod plugs were taken from a mature stand of 'Patriot' hybrid bermudagrass, washed free of soil, and transplanted into plastic pots with a surface area of $50 \mathrm{~cm}^{2}$ and a $18-\mathrm{cm}$ depth. A commercial greenhouse mix (Humin Substrat N17, pH 6.0, EC $0.40 \mathrm{dS} \cdot \mathrm{m}^{-1}$; KlasmannDeilmann, Geestee, Germany) was used as a growing medium. Before initiating the study, plants were allowed to establish for 3 weeks. During establishment, pots were kept in the greenhouse and the temperature maintained at an approximate day/night temperature of $35 / 20^{\circ} \mathrm{C}$ with daily maximum photosynthetically active radiation levels ranging from 950 to 1425 $\mu \mathrm{mol} \cdot \mathrm{m}^{-2} \cdot \mathrm{s}^{-1}$, provided by sunlight. Irrigation was supplemented to encourage active growth, and fertilization was carried out with a slow release fertilizer (Landscape Pro Universtar $15 \mathrm{~N}-2.6 \mathrm{P}-13.3 \mathrm{~K}$; Everris Italia, Treviso, Italy) providing a total amount of $200.0 \mathrm{~kg} \cdot \mathrm{ha}^{-1}$ nitrogen $(\mathrm{N}), \quad 29.2 \mathrm{~kg} \cdot \mathrm{ha}^{-1}$ phosphorous (P), and $176.8 \mathrm{~kg} \cdot \mathrm{ha}^{-1}$ potassium (K) over the trial period. Pots were mown twice per week to a height of $1.5 \mathrm{~cm}$, and mowing suspended after treatment application.

Nine PGRs and an untreated control were included in the trial. Their common name, the commercial product used, the active ingredient concentration, and the abbreviation adopted in this article are reported in Table 1. PGRs are listed according to the classification proposed by Ervin and Zhang (2008). To explore the effects of the products beyond their labeled range of application, each product was applied at eight different 
rates. Rates were progressively increased from Rate 1 (Rl) to Rate 8 (R8) with each consecutive rate having a 2 -fold increase of the active ingredient concentration compared with the previous one.

The lowest rates of TE and PB were intended to approximate the highest suggested application rate labeled for turfgrass use. The lowest $\mathrm{CM}$ application rate was set to approximate that recommended for open-field application on grain crops. PPC was applied at rates ranging from below the minimum and above the maximum effective rates for fungicidal effects on turfgrass. DQ, FS, and GP concentrations were calculated in order for most of the treatments to have an application rate below that required for a herbicidal effect. The lowest application rates for EP and GA were intended to approximate the highest suggested application rate labeled for turfgrass use. Table 2 reports the eight application rates adopted for each active ingredient in the experimental treatments.

Treatments were applied once on 7 May 2013 by a pressurized carbon dioxide $\left(\mathrm{CO}_{2}\right)$ sprayer. To achieve fully wet leaves without product runoff, preliminary trials were carried out and $1 \mathrm{~mL}$ of mix per pot (equivalent to a mix application of $2000 \mathrm{~L} \cdot \mathrm{ha}^{-1}$ ) was applied. Control pots were sprayed with tap water. Treatments were arranged in a randomized complete block experimental design with three replications. Starting from $2 \mathrm{~d}$ after treatment until 4 weeks after treatment (WAT), turf injury and turf color were visually assessed on a weekly basis. Turf injury was reported as percentage with $0=$ no injury and $100=$ complete kill of the turf and turf color was reported with a 1 to 9 scale, where $1=$ light green, and $9=$ dark green. At 4 WAT biometric measurements were also carried out. Turf height was measured with a $50 \mathrm{~cm}^{2}$ disk (specific density $0.75 \mathrm{~kg} \cdot \mathrm{m}^{-2}$ ) left to rest on the sward surface and the distance between the lower surface of the disc and the pot rim measured with a ruler (data reported in millimeters). Leaf length was determined by measuring 10 fully expanded leaf blades per pot with a ruler (data reported in centimeters). The number of stolons per pot was determined by direct counting of the number of stolons exceeding the pot rim while mean stolon length was determined by measuring with a ruler, all stolons exceeding the pot rim and calculating mean length (data reported in centimeters). Internode diameter (reported in millimeters) was determined by taking 10 random measurements per pot with a digital micrometer (Mitutoyo Corp., Kawasaki, Japan) and internode length was determined by measuring 10 random internodes per pot with a precision Vernier caliper (data reported in millimeters). After the above determination, at 4 WAT the turf was cut at pot rim height, clippings collected and oven dried at $80^{\circ} \mathrm{C}$ until constant weight, weighed and aerial biomass determined (data reported in grams per pot).

Data were subject to analysis of variance using CoStat 6.400 (CoHort Software, Monterey, CA). Fisher's protected least significant difference at a $5 \%$ probability level was used to compare means among application rates for each active ingredient separately.

\section{Results}

Data referring to turf injury are discussed first to identify those treatments that cause direct damage to hybrid bermudagrass and thus have

Table 2. Plant growth regulators applied at increasing rates on pot-grown 'Patriot' hybrid bermudagrass to control stolon development and elongation: application rates and relative abbreviations. Rates are increased from Rate $1(R \mathbf{l})$ to Rate 8 ( $\mathrm{R8}$ ); each consecutive rate has a 2 -fold increase of the active ingredient concentration compared with the previous one.

\begin{tabular}{lrrrrrrrrrr}
\hline & \multicolumn{8}{c}{ Active ingredient $^{\mathbf{z}}$} \\
\cline { 2 - 11 } $\begin{array}{l}\text { Application } \\
\text { rate abbreviation }\end{array}$ & TE & CM & PB & PPC & DQ & FS & GP & EP & GA \\
\cline { 2 - 11 } & \multicolumn{7}{c}{ Application rate $\left(\mathrm{kg} \cdot \mathbf{h a}^{-\mathbf{1}}\right.$} & $\mathbf{a . i})^{\mathbf{y}}$ & & \\
\hline R1 & 0.5 & 2.0 & 0.5 & 0.05 & 0.05 & 0.001 & 0.05 & 2.0 & 0.02 \\
R2 & 1.0 & 4.0 & 1.0 & 0.1 & 0.1 & 0.002 & 0.1 & 4.0 & 0.04 \\
R3 & 2.0 & 8.0 & 2.0 & 0.2 & 0.2 & 0.004 & 0.2 & 8.0 & 0.08 \\
R4 & 4.0 & 16.0 & 4.0 & 0.4 & 0.4 & 0.008 & 0.4 & 16.0 & 0.16 \\
R5 & 8.0 & 32.0 & 8.0 & 0.8 & 0.8 & 0.016 & 0.8 & 32.0 & 0.32 \\
R6 & 16.0 & 64.0 & 16.0 & 1.6 & 1.6 & 0.032 & 1.6 & 64.0 & 0.64 \\
R7 & 32.0 & 128.0 & 32.0 & 3.2 & 3.2 & 0.064 & 3.2 & 128.0 & 1.28 \\
R8 & 64.0 & 256.0 & 64.0 & 6.4 & 6.4 & 0.128 & 6.4 & 256.0 & 2.56 \\
\hline
\end{tabular}

${ }^{2} \mathrm{TE}=$ trinexapac-ethyl $\mathrm{CM}=$ chlormequat; $\mathrm{PB}=$ paclobutrazol; $\mathrm{PPC}=$ propiconazole $; \mathrm{DQ}=$ diquat; $\mathrm{FS}=$ flazasulfuron; $\mathrm{GP}=$ glyphosate; $\mathrm{EP}=$ ethephon; $\mathrm{GA}=$ gibberellic acid $\left(\mathrm{GA}_{3}\right)$.

${ }^{\mathrm{y}} \mathrm{l} \mathrm{kg} \cdot \mathrm{ha}^{-1}=0.8922 \mathrm{lb} /$ acre.

Table 3. Plant growth regulators applied at increasing rates on pot-grown 'Patriot' hybrid bermudagrass to control stolon development and elongation: turf injury percentage recorded at 5 weeks after treatment.

\begin{tabular}{|c|c|c|c|c|c|c|c|c|c|}
\hline \multirow[b]{3}{*}{ Application rate } & \multicolumn{9}{|c|}{ Active ingredient ${ }^{\mathrm{y}}$} \\
\hline & $\overline{\mathrm{TE}^{\mathrm{z}}}$ & CM & PB & PPC & DQ & FS & GP & EP & GA \\
\hline & \multicolumn{9}{|c|}{ Turf injury $(\%)^{x}$} \\
\hline Control & 0 & 0 & 0 & 0 & 0 & 0 & 0 & 0 & 0 \\
\hline $\mathrm{Rl}$ & 0 & 0 & 0 & 3 & 5 & 0 & 5 & 0 & 0 \\
\hline R2 & 0 & 0 & 0 & 5 & 11 & 0 & 8 & 5 & 0 \\
\hline R3 & 5 & 2 & 0 & 4 & 14 & 0 & 13 & 5 & 0 \\
\hline R4 & 9 & 2 & 0 & 6 & 37 & 0 & 40 & 10 & 0 \\
\hline R5 & 20 & 7 & 0 & 5 & 51 & 0 & 89 & 16 & 0 \\
\hline R6 & 31 & 22 & 0 & 10 & 85 & 0 & 96 & 31 & 0 \\
\hline R7 & 78 & 30 & 0 & 28 & 93 & 0 & 100 & 40 & 0 \\
\hline R8 & 95 & 73 & 0 & 56 & 100 & 0 & 100 & 63 & 0 \\
\hline $\operatorname{LSD}(0.05)^{\mathrm{w}}$ & 28 & 20 & - & 21 & 25 & . & 24 & 20 & \\
\hline
\end{tabular}

${ }^{\mathrm{z}} \mathrm{Rl}$ to $\mathrm{R} 8$ represent increasing rates in the application of the different active ingredients. Each increase in rate is obtained by doubling the active ingredient concentration in the sprayed mix. Actual rates vary depending on the active ingredient (Table 2 )

${ }^{\mathrm{y}} \mathrm{TE}=$ trinexapac-ethyl; $\mathrm{CM}=$ chlormequat; $\mathrm{PB}=$ paclobutrazol; $\mathrm{PPC}=$ propiconazole; $\mathrm{DQ}=$ diquat; $\mathrm{FS}=$ flazasulfuron; $\mathrm{GP}=$ glyphosate; $\mathrm{EP}=$ ethephon; $\mathrm{GA}=$ gibberellic acid $\left(\mathrm{GA}_{3}\right)$.

${ }^{x}$ Turf injury was visually assessed and values are reported as percentages, with 0 indicating no injury and 100 indicating complete kill of the turf.

wFisher's protected least significant difference at $P \leq 0.05$. 
no potential application. With respect to turf injury, some treatments were well tolerated by plants regardless of the application rate, while in most cases treatments were increasingly harmful to plants as the active ingredient application rate increased. Negative effects became evident 2 to $3 \mathrm{~d}$ following the application; however, some treatments took a few weeks to reach the full effect. Data reported in Table 3 refer to peak values of turf injury observed at 5 WAT. No leaf damage occurred in pots treated with $\mathrm{PB}, \mathrm{FS}$, and GA regardless of the application rate. PPC application at R7 resulted in significant damage compared with the control, and reached $56 \%$ injury at its highest application rate. TE, CM, and EP first produced significant damage when applied at R6 $(31 \%, 22 \%$, and $31 \%$ leaf damage, respectively). The maximum application rate (R8) of the same products increased the damage to $95 \%, 73 \%$, and $63 \%$, respectively. R4 was the lowest harmful application rate both for DQ and GP, with leaf burns covering 37\% and $40 \%$ of the surface, respectively. Herbicidal effects occurred at R8 for DQ $\left(6.4 \mathrm{~kg} \cdot \mathrm{ha}^{-1}\right)$, and at R7 and R8 for GP $\left(3.2\right.$ and $6.4 \mathrm{~kg} \cdot \mathrm{ha}^{-1}$, respectively). Because of the complete loss of the turf, further determinations were not carried out for these treatments.

The most marked differences in turf color were detected at 2 WAT. Data reported in Table 4 and the relative discussion refer to this assessment. Color was unaffected by PB, PPC, and FS at any of the application rates, with scores not differing statistically from the value $(7.0)$ recorded for the control (Table 4). TE was the only active ingredient that improved turf color compared with the control: when applied at R1 and R2 (1.0 and $2.0 \mathrm{~kg} \cdot \mathrm{ha}^{-1}$, respectively) color was scored 7.5 and 7.8, respectively. When applied at rates $\mathrm{R} 3, \mathrm{R} 4$, and $\mathrm{R} 5$, no effect on color was detectable, while the effect became negative when application rates were higher than $\mathrm{R} 5\left(8.0 \mathrm{~kg} \cdot \mathrm{ha}^{-1}\right)$. For all the remaining active ingredient treatments, a discoloration was generally associated with the progressive increase in application rate. Reductions in color score were induced by higher application rates than $\mathrm{R} 2$ for $\mathrm{DQ}$ and GA, higher than R3 for GP, higher

Table 4. Plant growth regulators applied at increasing rates on pot-grown 'Patriot' hybrid bermudagrass to control stolon development and elongation: turf color (1-9 scale) recorded at 2 weeks after treatment.

\begin{tabular}{lccccccccc}
\hline & \multicolumn{7}{c}{ Active ingredient $^{\mathrm{y}}$} \\
\cline { 2 - 10 } Application rate $^{\mathrm{z}}$ & TE & CM & PB & PPC & DQ & FS & GP & EP & GA \\
\cline { 2 - 10 } & & \multicolumn{7}{c}{ Turf color (1-9 } & scale) \\
Control & 7.0 & 7.0 & 7.0 & 7.0 & 7.0 & 7.0 & 7.0 & 7.0 & 7.0 \\
R1 & 7.5 & 6.8 & 7.4 & 6.4 & 6.5 & 7.2 & 6.4 & 7.2 & 6.4 \\
R2 & 7.8 & 7.1 & 7.6 & 6.3 & 6.7 & 7.1 & 6.5 & 6.9 & 6.3 \\
R3 & 7.0 & 6.9 & 7.6 & 6.6 & 6.4 & 7.3 & 6.6 & 6.8 & 6.1 \\
R4 & 7.2 & 7.0 & 7.4 & 6.5 & 6.2 & 7.0 & 6.2 & 7.3 & 6.2 \\
R5 & 6.8 & 6.6 & 7.3 & 6.7 & 6.1 & 7.4 & 4.5 & 7.0 & 5.6 \\
R6 & 5.2 & 6.4 & 7.4 & 7.1 & 6.3 & 6.5 & 3.0 & 6.5 & 5.4 \\
R7 & 2.1 & 5.9 & 7.5 & 7.2 & 4.0 & 6.9 & - & 5.9 & 5.5 \\
R8 & 1.0 & 6.0 & 7.0 & 6.9 & 2.0 & 6.5 & - & 5.8 & 5.0 \\
LSD $(0.05)^{\mathrm{w}}$ & 0.5 & 0.6 & NS $^{\mathrm{v}}$ & NS & 0.6 & NS & 0.7 & 0.6 & 0.8 \\
\hline
\end{tabular}

${ }^{\mathrm{z}} \mathrm{Rl}$ to $\mathrm{R} 8$ represent increasing rates in the application of the different active ingredients. Each increase in rate is obtained by doubling the active ingredient concentration in the sprayed mix. Actual rates vary depending on the active ingredient (Table 2).

$\mathrm{y}_{\mathrm{TE}}=$ trinexapac-ethyl $\mathrm{CM}=$ chlormequat; $\mathrm{PB}=$ paclobutrazol; $\mathrm{PPC}=$ propiconazole $; \mathrm{DQ}=$ diquat; $\mathrm{FS}=$ flazasulfuron; $\mathrm{GP}=$ glyphosate; $\mathrm{EP}=$ ethephon; $\mathrm{GA}=$ gibberellic acid $\left(\mathrm{GA}_{3}\right)$.

x Turf color was visually assessed and values are reported on a 1 to 9 scale, with 1 indicating light green and 9 indicating dark green.

${ }^{w}$ Fisher's protected least significant difference for $P \leq 0.05$.

Nonsignificant at $P \leq 0.05$.

Table 5. Plant growth regulators applied at increasing rates on pot-grown 'Patriot' hybrid bermudagrass to control stolon development and elongation: turf height measured at 4 weeks after treatment.

\begin{tabular}{lrrrrrrrrr}
\hline & \multicolumn{8}{c}{ Active ingredient $^{\mathbf{y}}$} \\
\cline { 2 - 10 } Application rate $^{\mathbf{z}}$ & \multicolumn{10}{c}{ TE } & CM & PB & PPC & DQ & FS & GP & EP & GA \\
\cline { 2 - 10 } Control & 53 & 53 & 53 & 53 & 53 & 53 & 53 & 53 & 53 \\
R1 & 35 & 38 & 35 & 48 & 50 & 43 & 52 & 45 & 55 \\
R2 & 29 & 34 & 32 & 52 & 41 & 51 & 40 & 37 & 59 \\
R3 & 19 & 32 & 29 & 53 & 37 & 54 & 40 & 37 & 63 \\
R4 & 20 & 30 & 30 & 49 & 37 & 50 & 25 & 42 & 65 \\
R5 & 18 & 28 & 21 & 57 & 38 & 50 & 11 & 45 & 80 \\
R6 & 14 & 28 & 15 & 48 & 36 & 49 & 17 & 42 & 90 \\
R7 & 11 & 28 & 18 & 49 & 25 & 45 & - & 36 & 105 \\
R8 & 9 & 30 & 14 & 48 & 25 & 49 & - & 28 & 135 \\
LSD $(0.05)^{\mathrm{w}}$ & 10 & 8 & 10 & NS & 11 & NS & 12 & 8 & 15 \\
\hline
\end{tabular}

${ }^{2} \mathrm{Rl}$ to $\mathrm{R} 8$ represent increasing rates in the application of the different active ingredients. Each increase in rate is obtained by doubling the active ingredient concentration in the sprayed mix. Actual rates vary depending on the active ingredient (Table 2).

${ }^{\mathrm{y}} \mathrm{TE}=$ trinexapac-ethyl; $\mathrm{CM}=$ chlormequat; $\mathrm{PB}=$ paclobutrazol; $\mathrm{PPC}=$ propiconazole $; \mathrm{DQ}=$ diquat; $\mathrm{FS}=$ flazasulfuron; GP = glyphosate; $\mathrm{EP}=$ ethephon; $\mathrm{GA}=$ gibberellic acid $\left(\mathrm{GA}_{3}\right)$.

${ }^{x}$ Turf height was measured with a ruler and a rising disk with specific density of $0.75 \mathrm{~kg} \cdot \mathrm{m}^{-2}\left(0.154 \mathrm{lb} / \mathrm{ft}^{2}\right) ; 1 \mathrm{~mm}=$ 0.0394 inch.

"Fisher's protected least significant difference for $P \leq 0.05$

Nonsignificant at $P \leq 0.05$.

than R5 for CM, and higher than R6 for EP.

At 4 WAT, turf height in unmown control pots reached $53 \mathrm{~mm}$ (Table 5 ). The effect of treatments on turf height was negligible when PPC and FS were applied. TE, CM, PB, and $\mathrm{EP}$ reduced turf height starting from the lowest application rate. $\mathrm{TE}$ and $\mathrm{PB}$ showed a strong association between application rate and height reduction. Turf height was reduced compared with the control when DQ and GP were applied at R2 $\left(0.1 \mathrm{~kg} \cdot \mathrm{ha}^{-1}\right)$ or higher rates. As expected, GA was the only active ingredient to cause an increase in turf height. The turf was higher compared with the control pots when GA was applied at rates from R5 to R8 (0.32 to $\left.2.56 \mathrm{~kg} \cdot \mathrm{ha}^{-1}\right)$.

Except for PPC, leaf length was affected by all treatments. CM, FS, and EP caused a reduction in leaf 
elongation starting from the lowest application rate (RI), with little effect following further increases in the rate applied (Table 6). TE, PB, DQ, and GP also reduced leaf length, but with a stronger association with the application rate. In comparison with the control, shorter leaves were recorded at $\mathrm{Rl}$ for TE $\left(0.5 \mathrm{~kg} \cdot \mathrm{ha}^{-1}\right)$, at R5 for PB $\left(8.0 \mathrm{~kg} \cdot \mathrm{ha}^{-1}\right)$, at R2 for GP $\left(0.1 \mathrm{~kg} \cdot \mathrm{ha}^{-1}\right)$, and at R7 $\left(3.2 \mathrm{~kg} \cdot \mathrm{ha}^{-1}\right)$ for DQ. As expected, GA was again the only active ingredient to stimulate leaf elongation with the leaf length ranging from 5.5 to $7.7 \mathrm{~cm}$ when GA was applied at rates from $\mathrm{Rl}$ to $\mathrm{R} 8(0.02$ to $2.56 \mathrm{~kg} \cdot \mathrm{ha}^{-1}$ ), with $3.6 \mathrm{~cm}$ recorded as the average length in untreated control pots.

In untreated control pots, there was an average of 26 stolons per pot (Table 7). This average was unaffected by the application of FS and EP at any of the application rates tested in the trial. CM, DQ, and GP enhanced stolon production compared with the control at $\mathrm{Rl}$ and R2. PB had the same effect only at $\mathrm{Rl}$. This effect of stimulation on stolon production was not consistent when CM was applied at higher rates than R2, while it reverted to an inhibiting effect when $\mathrm{PB}, \mathrm{DQ}$, and GP were applied at rates equal or higher than R3, R6, and R4, respectively. TE and PPC did not produce any effect on stolon number with $\mathrm{Rl}$ to R3 application rates. For higher rates, the treatments reduced the number of stolons compared with the control pots. GA had no effect on stolon number at $\mathrm{Rl}$ and $\mathrm{R} 2$ application rates, while higher application rates reduced the number of stolons per pot. In addition a prevailing vertical growth of stems was associated with increasing application rates of GA, which probably explains the reduced number of stems with the morphological characteristics of stolons.

Mean stolon length recorded in control pots was $6.8 \mathrm{~cm}$, and treatments with CM did not affect this parameter (Table 8$)$. The pots treated with $\mathrm{TE}, \mathrm{PB}$, and PPC produced shorter stolons than untreated pots when products were applied at rates equal or higher than R3 $\left(2.0 \mathrm{~kg} \cdot \mathrm{ha}^{-1}\right)$, R2 $\left(1.0 \mathrm{~kg} \cdot \mathrm{ha}^{-1}\right)$, or R8 $\left(6.4 \mathrm{~kg} \cdot \mathrm{ha}^{-1}\right)$, respectively.

For DQ, the lowest rates did not have any effects on stolon length

Table 6. Plant growth regulators applied at increasing rates on pot-grown 'Patriot' hybrid bermudagrass to control stolon development and elongation: leaf length measured at 4 weeks after treatment.

\begin{tabular}{|c|c|c|c|c|c|c|c|c|c|}
\hline \multirow[b]{3}{*}{ Application rate ${ }^{\mathrm{z}}$} & \multicolumn{9}{|c|}{ Active ingredient $\mathrm{t}^{\mathrm{y}}$} \\
\hline & $\mathrm{TE}^{\mathrm{z}}$ & $\mathbf{C M}$ & PB & PPC & DQ & FS & GP & EP & GA \\
\hline & \multicolumn{9}{|c|}{ Leaf length $(\mathrm{cm})^{x}$} \\
\hline Control & 3.6 & 3.6 & 3.6 & 3.6 & 3.6 & 3.6 & 3.6 & 3.6 & 3.6 \\
\hline $\mathrm{Rl}$ & 2.4 & 2.3 & 2.8 & 3.0 & 3.6 & 2.5 & 3.5 & 1.9 & 5.5 \\
\hline $\mathrm{R} 2$ & 1.6 & 2.6 & 2.5 & 2.9 & 3.8 & 2.3 & 2.5 & 1.6 & 5.9 \\
\hline R3 & 1.5 & 2.1 & 2.4 & 2.3 & 3.5 & 2.2 & 2.4 & 1.8 & 6.0 \\
\hline $\mathrm{R} 4$ & 1.8 & 2.2 & 2.2 & 3.7 & 3.6 & 2.5 & 2.4 & 1.9 & 6.2 \\
\hline R5 & 1.5 & 1.9 & 1.2 & 3.7 & 3.2 & 2.4 & 1.8 & 1.8 & 6.4 \\
\hline R6 & 1.3 & 1.9 & 0.5 & 3.5 & 2.6 & 2.3 & 1.7 & 1.7 & 6.5 \\
\hline R7 & 0.7 & 2.1 & 0.7 & 2.7 & 1.9 & 2.3 & - & 1.4 & 6.7 \\
\hline R8 & 0.4 & 2.3 & 0.6 & 2.8 & 1.9 & 2.5 & - & 1.4 & 7.7 \\
\hline$\underline{\operatorname{LSD}(0.05)^{\mathrm{w}}}$ & 1.1 & 1.0 & 1.5 & $\mathrm{NS}^{\mathrm{v}}$ & 1.6 & 1.1 & 0.9 & 1.0 & 1.4 \\
\hline
\end{tabular}

${ }^{\mathrm{z}} \mathrm{Rl}$ to $\mathrm{R} 8$ represent increasing rates in the application of the different active ingredients. Each increase in rate is obtained by doubling the active ingredient concentration in the sprayed mix. Actual rates vary depending on the active ingredient (Table 2).

${ }^{y} \mathrm{TE}=$ trinexapac-ethyl; $\mathrm{CM}=$ chlormequat; $\mathrm{PB}=$ paclobutrazol; $\mathrm{PPC}=$ propiconazole; $\mathrm{DQ}=$ diquat; $\mathrm{FS}=$ flazasulfuron; $\mathrm{GP}=$ glyphosate; $\mathrm{EP}=$ ethephon; $\mathrm{GA}=$ gibberellic acid $\left(\mathrm{GA}_{3}\right)$.

${ }^{x}$ Leaf length was measured with a ruler; $1 \mathrm{~cm}=0.3937$ inch.

"Fisher's protected least significant difference for $P \leq 0.05$.

"Nonsignificant at $P \leq 0.05$.

Table 7. Plant growth regulators applied at increasing rates on pot-grown 'Patriot' hybrid bermudagrass to control stolon development and elongation: number of stolons per pot measured at 4 weeks after treatment.

\begin{tabular}{lrrrrrrrrr}
\hline & \multicolumn{7}{c}{ Active ingredient $^{\mathbf{y}}$} \\
\cline { 2 - 10 } Application rate $^{\mathbf{z}}$ & TE $^{\mathbf{z}}$ & $\mathbf{C M}$ & PB & PPC & DQ & FS & GP & EP & GA \\
\cline { 2 - 10 } Control & 26 & 26 & 26 & 26 & 26 & 26 & 26 & 26 & 26 \\
R1 & 28 & 42 & 37 & 21 & 35 & 25 & 37 & 30 & 20 \\
R2 & 24 & 35 & 29 & 21 & 32 & 20 & 38 & 31 & 21 \\
R3 & 22 & 32 & 20 & 20 & 24 & 21 & 21 & 28 & 14 \\
R4 & 15 & 34 & 18 & 13 & 22 & 23 & 13 & 28 & 13 \\
R5 & 13 & 32 & 16 & 12 & 23 & 21 & 4 & 26 & 10 \\
R6 & 10 & 31 & 15 & 10 & 20 & 24 & 7 & 25 & 8 \\
R7 & 5 & 29 & 5 & 7 & 19 & 20 & - & 24 & 2 \\
R8 & 6 & 26 & 6 & 9 & 15 & 24 & - & 22 & 3 \\
LSD $(0.05)^{\mathrm{w}}$ & 8 & 7 & 5 & 7 & 6 & NS $^{\mathrm{v}}$ & 10 & NS & 7 \\
\hline
\end{tabular}

${ }^{\mathrm{z}} \mathrm{Rl}$ to $\mathrm{R} 8$ represent increasing rates in the application of the different active ingredients. Each increase in rate is obtained by doubling the active ingredient concentration in the sprayed mix. Actual rates vary depending on the active ingredient (Table 2 ).

${ }^{\mathrm{y}} \mathrm{TE}=$ trinexapac-ethyl; $\mathrm{CM}=$ chlormequat; $\mathrm{PB}=$ paclobutrazol; $\mathrm{PPC}=$ propiconazole $; \mathrm{DQ}=$ diquat $\mathrm{FS}=$ flazasulfuron; GP = glyphosate; $\mathrm{EP}=$ ethephon; $\mathrm{GA}=$ gibberellic acid $\left(\mathrm{GA}_{3}\right)$.

'Values refer to stolons exceeding the pot rim.

"Fisher's protected least significant difference for $P \leq 0.05$

'Nonsignificant at $P \leq 0.05$.

while, starting from R5 $\left(0.8 \mathrm{~kg} \cdot \mathrm{ha}^{-1}\right)$, increasing rates led to progressively increased lengths, with R8 $\left(6.4 \mathrm{~kg} \cdot \mathrm{ha}^{-1}\right)$ that yielded stolons that were on average $10.3 \mathrm{~cm}$ long. A similar effect was observed for GP, which induced a stolon elongation for rates ranging from R2 to R6, equivalent to application rates from 0.05 to $1.6 \mathrm{~kg} \cdot \mathrm{ha}^{-1}$. For FS, EP, and GA, the response of the stolon mean length to application rate was not linear. Plants had longer stolons compared with control pots when treated with FS at rates from $\mathrm{Rl}$ to $\mathrm{R} 5$, with $\mathrm{EP}$ at rates from $\mathrm{Rl}$ to $\mathrm{R} 6$, and with $\mathrm{GA}$ at rates from $\mathrm{Rl}$ to $\mathrm{R} 7$. With further increases in the rates of EP and GA, stolon length was not statistically different from the control. On the other hand, the treatments with FS at R7 and R8 application rates $\left(0.064\right.$ and $\left.0.128 \mathrm{~kg} \cdot \mathrm{ha}^{-1}\right)$ produced the reverse effect, thus stolons had a shorter length than the control. 
The mean internode diameter of untreated plants was $1.4 \mathrm{~mm}$ and most of the active ingredients tested in the trial did not affect this trait at any of the rates at which they were applied (Table 9). Exceptions were observed for TE, PB, and GA. Reductions of the internode diameter compared with the control were recorded for all rates of $\mathrm{TE}$, in the range $\mathrm{R} 6$ to $\mathrm{R} 8$ for $\mathrm{PB}$ (equivalent to rates varying from 16 to $64 \mathrm{~kg} \cdot \mathrm{ha}^{-1}$ ) and in the range R5 to R8 for GA (equivalent to rates varying from 0.32 to $\left.2.56 \mathrm{~kg} \cdot \mathrm{ha}^{-1}\right)$.

Mean internode length recorded in the control pots was $2.8 \mathrm{~mm}$, and this length was unaffected by treatments with CM, PPC, DQ, FS, and GA (Table 10). PB reduced the internode length in all the range of treatments, whereas TE and EP reduced internode length compared with the control for application rates equal or higher than R3 $\left(2.0 \mathrm{~kg} \cdot \mathrm{ha}^{-1}\right)$ and R7 (128.0 kg.ha $\left.{ }^{-1}\right)$, respectively.

GP led to an increase in internode elongation. Rates from R3 to R6 (0.08 to $\left.0.64 \mathrm{~kg} \cdot \mathrm{ha}^{-1}\right)$ caused the internodes to assume an average length of $4.3 \mathrm{~mm}$ with an increase of $53.6 \%$ compared with the untreated control.

Aerial biomass collected in the untreated control was $3.4 \mathrm{~g} /$ pot and its production was negatively affected by the increasing application rates of all the products except GA (Table 11 ). The lowest application rate ( $\mathrm{Rl}$ ) was effective in reducing biomass only for DQ $\left(0.05 \mathrm{~kg} \cdot \mathrm{ha}^{-1}\right)$. CM, PB, and EP started producing a reduction of biomass from R2 $\left(4.0,1.0\right.$, and $4.0 \mathrm{~kg} \cdot \mathrm{ha}^{-1}$, respectively). TE and GP reached a lower biomass production at rates equal or higher than R3 (2.0 and $0.2 \mathrm{~kg} \cdot \mathrm{ha}^{-1}$, respectively), while PPC and FS reached it at rates equal or higher than R6 (1.6 and $0.032 \mathrm{~kg} \cdot \mathrm{ha}^{-1}$, respectively). GA produced an increase in biomass production when applied at $2.56 \mathrm{~kg} \cdot \mathrm{ha}^{-1}(\mathrm{R} 8)$.

\section{Discussion}

Of the tested active ingredients only TE, PB, and PPC consistently reduced stolon length. Results for TE applied at rates higher than the labeled range are in accordance with observations reported by Volterrani et al. (2012). Although PB was reported to be ineffective in controlling lateral stolon growth when

Table 8. Plant growth regulators applied at increasing rates on pot-grown 'Patriot' hybrid bermudagrass to control stolon development and elongation: mean stolon length measured at 4 weeks after treatment.

\begin{tabular}{|c|c|c|c|c|c|c|c|c|c|}
\hline \multirow[b]{3}{*}{ Application rate ${ }^{\mathrm{z}}$} & \multicolumn{9}{|c|}{ Active ingredient $\mathrm{t}^{\mathrm{y}}$} \\
\hline & $\mathrm{TE}^{\mathrm{z}}$ & $\mathbf{C M}$ & PB & PPC & DQ & FS & GP & EP & GA \\
\hline & \multicolumn{9}{|c|}{ Mean stolon length $(\mathrm{cm})^{\mathrm{x}}$} \\
\hline Control & 6.8 & 6.8 & 6.8 & 6.8 & 6.8 & 6.8 & 6.8 & 6.8 & 6.8 \\
\hline $\mathrm{Rl}$ & 6.7 & 6.9 & 6.1 & 7.0 & 6.8 & 14.0 & 8.6 & 9.2 & 8.3 \\
\hline $\mathrm{R} 2$ & 6.5 & 8.0 & 5.0 & 6.9 & 7.2 & 16.7 & 8.9 & 9.3 & 8.6 \\
\hline R3 & 4.6 & 8.1 & 4.0 & 7.2 & 8.0 & 15.4 & 15.4 & 9.4 & 8.4 \\
\hline $\mathrm{R} 4$ & 4.4 & 7.4 & 2.7 & 7.7 & 8.3 & 9.6 & 15.6 & 8.7 & 8.9 \\
\hline $\mathrm{R} 5$ & 4.5 & 7.2 & 1.6 & 8.3 & 8.8 & 8.5 & 15.0 & 9.8 & 11.0 \\
\hline R6 & 2.7 & 6.9 & 1.3 & 8.3 & 9.8 & 6.3 & 11.0 & 9.0 & 11.1 \\
\hline R7 & 2.6 & 6.2 & 0.7 & 5.5 & 9.8 & 5.5 & - & 7.8 & 9.0 \\
\hline R8 & 1.3 & 6.0 & 1.5 & 4.2 & 10.3 & 4.6 & - & 7.8 & 5.8 \\
\hline $\operatorname{LSD}(0.05)^{\mathrm{w}}$ & 0.8 & $\mathrm{NS}^{\mathrm{v}}$ & 0.8 & 1.6 & 1.9 & 0.7 & 1.9 & 1.2 & 1.1 \\
\hline
\end{tabular}

${ }^{\mathrm{z}} \mathrm{Rl}$ to $\mathrm{R} 8$ represent increasing rates in the application of the different active ingredients. Each increase in rate is obtained by doubling the active ingredient concentration in the sprayed mix. Actual rates vary depending on the active ingredient (Table 2).

$\mathrm{y}_{\mathrm{TE}}=$ trinexapac-ethyl; $\mathrm{CM}=$ chlormequat; $\mathrm{PB}=$ paclobutrazol; $\mathrm{PPC}=$ propiconazole $; \mathrm{DQ}=$ diquat; $\mathrm{FS}=$ flazasulfuron; $\mathrm{GP}=$ glyphosate; $\mathrm{EP}=$ ethephon; $\mathrm{GA}=$ gibberellic acid $\left(\mathrm{GA}_{3}\right)$.

${ }^{x}$ Mean stolon length was calculated on stolons exceeding the pot rim; $1 \mathrm{~cm}=0.3937 \mathrm{inch}$

"Fisher's protected least significant difference for $P \leq 0.05$.

'Nonsignificant at $P \leq 0.05$.

Table 9. Plant growth regulators applied at increasing rates on pot-grown 'Patriot' hybrid bermudagrass to control stolon development and elongation: mean internode diameter measured at 4 weeks after treatment.

\begin{tabular}{|c|c|c|c|c|c|c|c|c|c|}
\hline \multirow[b]{3}{*}{ Application rate } & \multicolumn{9}{|c|}{ Active ingredient ${ }^{\mathrm{y}}$} \\
\hline & $\mathrm{TE}^{\mathrm{z}}$ & $\mathbf{C M}$ & PB & PPC & DQ & FS & GP & EP & GA \\
\hline & \multicolumn{9}{|c|}{ Mean internode diam $(\mathrm{mm})^{\mathrm{x}}$} \\
\hline Control & 1.4 & 1.4 & 1.4 & 1.4 & 1.4 & 1.4 & 1.4 & 1.4 & 1.4 \\
\hline $\mathrm{Rl}$ & 1.2 & 1.6 & 1.6 & 1.3 & 1.4 & 1.5 & 1.2 & 1.4 & 1.4 \\
\hline $\mathrm{R} 2$ & 1.2 & 1.6 & 1.6 & 1.4 & 1.5 & 1.5 & 1.2 & 1.4 & 1.5 \\
\hline R3 & 1.2 & 1.5 & 1.7 & 1.3 & 1.3 & 1.5 & 1.2 & 1.4 & 1.4 \\
\hline $\mathrm{R} 4$ & 1.2 & 1.4 & 1.5 & 1.4 & 1.2 & 1.5 & 1.3 & 1.5 & 1.3 \\
\hline $\mathrm{R} 5$ & 1.2 & 1.5 & 1.3 & 1.4 & 1.2 & 1.5 & 1.1 & 1.4 & 1.1 \\
\hline R6 & 1.1 & 1.5 & 0.9 & 1.4 & 1.3 & 1.5 & 1.2 & 1.2 & 1.0 \\
\hline R7 & 1.0 & 1.4 & 0.9 & 1.2 & 1.3 & 1.4 & - & 1.3 & 0.9 \\
\hline $\mathrm{R} 8$ & 0.8 & 1.4 & 0.9 & 1.3 & 1.3 & 1.4 & - & 1.4 & 0.7 \\
\hline $\operatorname{LSD}(0.05)^{\mathrm{w}}$ & 0.2 & $\mathrm{NS}^{\mathrm{v}}$ & 0.4 & NS & NS & NS & NS & NS & 0.2 \\
\hline
\end{tabular}

${ }^{\mathrm{z}} \mathrm{Rl}$ to $\mathrm{R} 8$ represent increasing rates in the application of the different active ingredients. Each increase in rate is obtained by doubling the active ingredient concentration in the sprayed mix. Actual rates vary depending on the active ingredient (Table 2).

${ }^{\mathrm{T}} \mathrm{TE}=$ trinexapac-ethyl; $\mathrm{CM}=$ chlormequat; $\mathrm{PB}=$ paclobutrazol $\mathrm{PPC}=$ propiconazole; $\mathrm{DQ}=$ diquat; $\mathrm{FS}=$ flazasulfuron; $\mathrm{GP}=$ glyphosate; $\mathrm{EP}=$ ethephon; $\mathrm{GA}=$ gibberellic acid $\left(\mathrm{GA}_{3}\right)$.

${ }^{\mathrm{x}}$ Mean internode diameter measured by a micrometer on 10 random internodes per pot; $1 \mathrm{~mm}=0.0394$ inch. "Fisher's protected least significant difference for $P \leq 0.05$.

'Nonsignificant at $P \leq 0.05$.

applied on st. augustinegrass (Stenotaphrum secundatum) at rate of 1.12 $\mathrm{kg} \cdot \mathrm{ha}^{-1}$ (McCarty et al., 2004), in this study application rates of $\mathrm{PB}$ equal or higher than $1.0 \mathrm{~kg} \cdot \mathrm{ha}^{-1}$ had a significant effect on 'Patriot' hybrid bermudagrass stolon length. Available data on clipping reductions are confirmed in this study. The reduced elongation of stolons recorded for PPC in bermudagrass seems to confirm the ability of triazoles to interfere with plant hormones that are involved in cell elongation and division (Hartwig et al., 2012). Contrary to findings reported by Youngner and Nudjie (1974), CM had no detectable effect on stolon elongation.

Increasing the application rate of DQ and GP led to stolon elongation, while increasing rates of FS, EP, and GA produced inconsistent effects with lower rates inducing elongation, and higher rates losing this effect (EP and GA) or reducing the length (FS). 
Table 10. Plant growth regulators applied at increasing rates on pot-grown 'Patriot' hybrid bermudagrass to control stolon development and elongation: internode length measured at 4 weeks after treatment.

\begin{tabular}{|c|c|c|c|c|c|c|c|c|c|}
\hline \multirow[b]{3}{*}{ Application rate ${ }^{\mathrm{z}}$} & \multicolumn{9}{|c|}{ Active ingredient ${ }^{\mathrm{y}}$} \\
\hline & $\mathrm{TE}^{\mathrm{z}}$ & $\mathbf{C M}$ & PB & PPC & DQ & FS & GP & EP & GA \\
\hline & \multicolumn{9}{|c|}{ Internode length $(\mathrm{cm})^{x}$} \\
\hline Control & 2.8 & 2.8 & 2.8 & 2.8 & 2.8 & 2.8 & 2.8 & 2.8 & 2.8 \\
\hline $\mathrm{Rl}$ & 2.4 & 2.3 & 1.8 & 2.5 & 3.4 & 3.1 & 2.9 & 3.6 & 2.2 \\
\hline $\mathrm{R} 2$ & 2.1 & 2.3 & 1.8 & 3.0 & 3.3 & 2.9 & 2.8 & 2.3 & 2.5 \\
\hline R3 & 1.3 & 2.4 & 1.8 & 2.9 & 3.4 & 2.8 & 4.3 & 2.1 & 2.5 \\
\hline $\mathrm{R} 4$ & 1.3 & 2.4 & 0.9 & 2.7 & 3.6 & 2.8 & 4.2 & 2.0 & 2.6 \\
\hline $\mathrm{R} 5$ & 1.2 & 2.2 & 0.7 & 3.0 & 3.3 & 2.6 & 4.2 & 2.1 & 2.8 \\
\hline R6 & 0.8 & 2.1 & 0.5 & 2.6 & 3.7 & 2.4 & 4.3 & 2.0 & 2.8 \\
\hline R7 & 0.7 & 2.4 & 0.3 & 2.8 & 3.6 & 2.5 & - & 1.8 & 2.0 \\
\hline R8 & 0.6 & 2.5 & 0.5 & 2.5 & 3.2 & 2.5 & - & 1.9 & 2.0 \\
\hline $\operatorname{LSD}(0.05)^{\mathrm{w}}$ & 0.8 & $\mathrm{NS}^{\mathrm{v}}$ & 0.9 & NS & NS & NS & 1.0 & 0.9 & NS \\
\hline
\end{tabular}

${ }^{\mathrm{z}} \mathrm{R} \mathrm{l}$ to $\mathrm{R} 8$ represent increasing rates in the application of the different active ingredients. Each increase in rate is obtained by doubling the active ingredient concentration in the sprayed mix. Actual rates vary depending on the active ingredient (Table 2 ).

${ }^{\mathrm{y}} \mathrm{TE}=$ trinexapac-ethyl $\mathrm{CM}=$ chlormequat; $\mathrm{PB}=$ paclobutrazol; $\mathrm{PPC}=$ propiconazole $; \mathrm{DQ}=$ diquat; $\mathrm{FS}=$ flazasulfuron; $\mathrm{GP}=$ glyphosate; $\mathrm{EP}=$ ethephon; $\mathrm{GA}=$ gibberellic acid $\left(\mathrm{GA}_{3}\right)$

Internode length was measured with a precision caliper; $1 \mathrm{~cm}=0.3937$ inch.

"Fisher's protected least significant difference for $P \leq 0.05$.

"Nonsignificant at $P \leq 0.05$.

Table 11. Plant growth regulators applied at increasing rates on pot-grown 'Patriot' hybrid bermudagrass to control stolon development and elongation: aboveground biomass measured at 4 weeks after treatment.

\begin{tabular}{lccccccccc}
\hline & \multicolumn{7}{c}{ Active ingredient $^{\mathbf{y}}$} \\
\cline { 2 - 10 } Application rate $^{\mathbf{z}}$ & TE $^{\mathbf{z}}$ & $\mathbf{C M}$ & PB & PPC & DQ & FS & GP & EP & GA \\
\cline { 2 - 10 } Control & 3.4 & 3.4 & 3.4 & 3.4 & 3.4 & 3.4 & 3.4 & 3.4 & 3.4 \\
R1 & 2.8 & 2.5 & 2.6 & 3.4 & 2.0 & 3.2 & 3.0 & 3.0 & 2.6 \\
R2 & 2.5 & 2.4 & 1.8 & 2.8 & 1.5 & 3.5 & 2.9 & 2.0 & 3.4 \\
R3 & 2.0 & 2.3 & 1.7 & 3.0 & 1.7 & 3.7 & 1.8 & 2.0 & 3.8 \\
R4 & 1.6 & 2.4 & 1.4 & 2.6 & 1.2 & 3.2 & 1.3 & 2.2 & 4.2 \\
R5 & 1.4 & 1.7 & 0.6 & 2.6 & 1.4 & 3.3 & 0.8 & 2.2 & 4.2 \\
R6 & 0.4 & 1.6 & 0.4 & 2.3 & 1.0 & 2.3 & 0.8 & 2.1 & 4.1 \\
R7 & 0.3 & 1.4 & 0.4 & 1.8 & 0.8 & 2.2 & - & 1.5 & 4.5 \\
R8 & 0.2 & 1.1 & 0.3 & 1.7 & 0.4 & 2.3 & - & 1.4 & 6.5 \\
LSD $(0.05)^{\mathrm{w}}$ & 1.0 & 1.0 & 1.2 & 1.0 & 0.9 & 0.9 & 1.1 & 1.0 & 1.5 \\
\hline
\end{tabular}

${ }^{\mathrm{z}} \mathrm{Rl}$ to $\mathrm{R} 8$ represent increasing rates in the application of the different active ingredients. Each increase in rate is obtained by doubling the active ingredient concentration in the sprayed mix. Actual rates vary depending on the active ingredient (Table 2 ).

$\mathrm{y}_{\mathrm{TE}}=$ trinexapac-ethyl $\mathrm{CM}=$ chlormequat $\mathrm{PB}=$ paclobutrazol; $\mathrm{PPC}=$ propiconazole $; \mathrm{DQ}=$ diquat; $\mathrm{FS}=$ flazasulfuron; GP = glyphosate; $\mathrm{EP}=$ ethephon; $\mathrm{GA}=$ gibberellic acid $\left(\mathrm{GA}_{3}\right)$.

${ }^{\mathrm{x}}$ Aerial biomass was determined by weighting clippings oven dried at $80^{\circ} \mathrm{C}\left(176.0{ }^{\circ} \mathrm{F}\right)$. Values are reported in grams dry weight per pot; $1 \mathrm{~g}=0.0353 \mathrm{oz}$

"Fisher's protected least significant difference for $P \leq 0.05$.

Although the reduction in stolon length obtained with PPC was not associated with an effect on internode length, when TE and PB were applied at R3 and R2, respectively, they reduced internode length from the reference value of $2.8 \mathrm{~cm}$ (untreated control) to 1.3 and 1.8 with reductions of $54 \%$ and $36 \%$, respectively.

For TE, PB, and PPC, the effects on stolon length reduction were often associated with a reduction in the number of stolons per pot. The only two treatments that reduced stolon length without reducing the number of stolons were $\mathrm{TE}$ at $\mathrm{R} 3$ and $\mathrm{PB}$ at R2. Further effects on plant morphology of TE applied at R3 were thinner stolons and shorter leaves compared with the untreated control.

Applying TE at R3 and PB at R2 did not affect the turf characteristics such as leaf burn or turf color, while turf height and aerial biomass were reduced by both treatments.
The application of $2.0 \mathrm{~kg} \cdot \mathrm{ha}^{-1}$ of TE or $1.0 \mathrm{~kg} \cdot \mathrm{ha}^{-1}$ of $\mathrm{PB}$ could represent potential suppression strategies of stolon elongation in pot-grown plants of hybrid bermudagrass.

\section{Literature cited}

Arteca, R.N. 1996. Plant growth substances: Principles and applications. Chapman Hall, New York, NY.

Brosnan, J.T., A.W. Thoms, G.K. Breeden, and J.C. Sorochan. 2010. Effects of various plant growth regulators on the traffic tolerance of 'Riviera' bermudagrass (Cynodon dactylon L.). HortScience 45:966-970.

Dunn, J. and K. Diesburg. 2004. Turf management in the transition zone. Wiley, Hoboken, NJ.

Ervin, E.H. and X. Zhang. 2008. Applied physiology of natural and synthetic plant growth regulators on turfgrasses, p. 171198. In: M. Pessarakli (ed.). Handbook of turfgrass management and physiology. CRC Press, Boca Raton, FL.

Ervin, E.H., X. Zhang, S.D. Askew, and J.M. Goatley. Jr. 2004. Trinexapac-ethyl, propiconazole, iron and biostimulant effects on shaded creeping bentgrass. HortTechnology 14:500-506.

Fletcher, R.A., A. Gilley, N. Sankhla, and T.D. Davis. 2000. Triazoles as plant growth regulators and stress protectants. Hort. Rev. 24:55-138.

Hartwig, T., C. Corvalan, N.B. Best, J.S. Budka, J.Y. Zhu, S. Choe, and B. Schulz. 2012. Propiconazole is a specific and accessible brassinosteroid (br) biosynthesis inhibitor for arabidopsis and maize. PLoS ONE 7(5):e36625.

Huang, B. 2007. Plant growth regulators: What and why. Golf Course Mgt. 75(1): 157-160.

Johnson, B.J. 1990. Response of bahiagrass (Paspalum notatum) to plant growth regulators. Weed Technol. 4:895-899.

Juska, F.V. 1958. Some effects of gibberellic acid on turfgrasses. Golf Course Rptr. 26(2):5-9.

McCarty, L.B. 2011. Best golf course management. Prentice Hall, Upper Saddle River, NJ.

McCarty, L.B., J.S. Weinbrecht, J.E. Toler, and G.L. Miller. 2004. St. augustinegrass response to plant growth retardants. Crop Sci. 44:1323-1329.

McCarty, L.B., T.G. Willis, J.E. Toler, and T. Whitwell. 2011. 'TifEagle' bermudagrass response to plant growth regulators and mowing height. Agron. J. 103:988-994. 


\section{Preliminary and Regional Reports}

McCullough, P.E. 2005a. Dwarf bermudagrass responses to flurprimidol and paclobutrazol. HortScience 40:1549-1551.

McCullough, P.E. 2005b. Physiological response of 'Tifeagle' bermudagrass to paclobutrazol. HortScience 40:224-226.

McCullough, P.E., H. Liu, L.B. McCarty, and T. Whitwell. 2004. Response of 'TifEagle' bermudagrass to seven plant growth regulators. HortScience 39:1759-1762.

McCullough, P.E., W. Nutt, T.M. Murphy, and P. Raymer. 2011. Seashore paspalum seedhead control and growth regulation with flazasulfuron and trinexapac-ethyl. Weed Technol. 25:64-69.
Meyer, J., P. Rein, P. Turner, and K. Mathias. 2013. Good management practices manual for the cane sugar industry. Bartens, Berlin, DE.

Sekimata, K., S.Y. Han, K. Yoneyama, Y. Takeuchi, S. Yoshida, and T. Asami. 2002. A specific and potent inhibitor of brassinosteroid biosynthesis possessing a dioxolane ring. J. Agr. Food Chem. 50:3486-3490.

Shatters, R.G., R. Wheeler, and S.H West. 1998. Ethephon induced changes in vegetative growth of 'Tifton 85' bermudagrass. Crop Sci. 38:97-103.

Youngner, V.B. and F.J. Nudjie. 1974. Growth retardant effects on various grass tissues and organs. Proc. Second Intl. Turfgrass Res. Conf. 458-462.

Volterrani, M., S. Magni, M. Gaetani, and F. Lulli. 2012. Trinexapac-ethyl effects on stolon activity and node vitality of 'Tifway' hybrid bermudagrass. HortTechnology 22:479-483.

Watschke, T.L., M.G. Prinster, and J.M. Breuninger. 1992. Plant growth regulators and turfgrass management, p. 557565. In: D.V. Waddington, R.N. Carrow, and R.C. Shearman (eds.). Turfgrass. Agron. Monogr. No. 32. Amer. Soc. Agron., Crop Sci. Soc. Amer., Soil Sci. Soc. Amer., Madison, WI. 